\title{
ENSAYO
}

\section{La pandemia covid-19 ¿Vértice de una nueva fase mundial?}

Mónica Jiménez Olmos, Socióloga y Psicoanalista, E-mail: socmona27@yahoo.com.mx

ORCID:

Fechas del Artículo:

Recibido: 30/01/2020

Dictamen: 05/05/2020

Aceptado: 25/09/2020

Publicado: $30 / 10 / 2020$
Forma de citar este artículo: Jiménez, M. (2020). La pan-

demia covid-19 ¿Vértice de una nueva fase mundial?, Revista Científica de Estudios Urbano Regionales HatsöHnini, Vol 1 No. 3 pp.78-79, DOI https:// doi.org/10.47386/2020V1N3E1

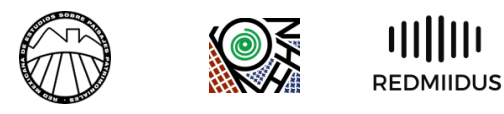

El presente año 2020 comenzó con un evento biopolítico en el mundo: la pandemia COVID 19- SARS -COV-2. Dicho fenómeno empezó a difundirse a través de los medios de comunicación de su importancia en la realidad cotidiana; afectando con ello las dinámicas sociales normales de muchos países en el mundo. Así, poco a poco se fue extendiendo el virus de Asia a Europa, América y África, a pesar de las medidas de prevención o extinción de los diferentes gobiernos, trastocando a su paso a todos En efecto este acontecimiento biopolítico ha sacudilos sectores de las sociedades. A partir de ello, se do la forma de organización y relaciones sociales tomaron en cuenta como lo hemos observado ya, en la actualidad, lo cual ha venido replantado frondistintas medidas, las cuales giran en torno al cierre teras ficticias endebles entre lo privado y lo público, de fronteras geográficas, limitación de la producción entre lo económico y lo político, lo biológico y el poy de los mercados económicos, reduciéndolo en der, lo virtual y lo físico, lo emocional y técnico. Dialgunos casos a mercancías de primera necesidad, chas delimitaciones sociales establecidas por los una cuarentena que implicaba el confinamiento poderes formales y fácticos (llámese leyes de vida (mantener a la gente en su espacio privado sin o muertes, sobrevivencia, extinción, depuración, aglomeraciones llamado también "quédate en ca- nuevos mercados, etc.) nos hacen preguntarnos, sa"), centros laborales trabajando como home offi- qué lugar ocupamos los ciudadanos frente a esta ce, desinfección de superficies vivas o no vivas, realidad que vivimos y sobre todo a las medidas etc.). El papel del cuidado del cuerpo, más no de asumidas por todos.

las emociones, ha sido un eje relevante en las cam- pañas de prevención de la pandemia, la finalidad en algunos países es combatir cualquier residuo del virus por la amenaza que representa, a estas medidas se le sumaron el llamado distanciamiento social, lo que por ejemplo en México, se representa como "la sana distancia", lo cual implicaba no tener contacto físico con otra personas alrededor de metro y medio, independiente a los vínculos o relación que se tuviese con ellas.

Si bien es cierto, es difícil analizar con todas las 


\section{La pandemia covid-19 ¿̇értice de una nueva fase mundial?}

\section{Mónica Jiménez Olmos}

variantes pertinentes la complejidad que estamos viviendo en estos tiempos por su vigencia y relevancia, también es cierto que se tiene que considerar las singularidades que se han presentado en los virtual.

diferentes continentes, países, y contextos socioculturales y económico-políticos, que van dando cause a sus propios marcos de referencia. Ahora bien, lo que aquí se pretende es reflexionar sobre algunas cuestiones que son efecto de la movilización que implica este acontecimiento histórico-biológico y que ha venido permeando las conductas, actitudes $y$ prácticas sociales en los diferentes integrantes y sectores de la sociedad. En dicho proceso se observa cómo se vislumbran nuevas formas de organización social, política, económica y personal mediadas todas por un común denominador: el poder mediático que se ha fortalecido y ha sido fundamental en la dinámica actual, tal como lo está siendo el medio virtual, es decir, el uso de los diferentes dispositivos por medio del uso del internet. Este poder mediático es uno de los factores y sectores que se ha visto potencializado por su uso y recurso en la organización y sobrevivencia de muchos sectores productivos y de consumo, por ejemplo, las compras, cursos, trabajo, convivencia, entretenimiento, arte, difusión, información, comunicación, desinformación etc., son actividades que se realizan y que continúan en medio de los distanciamiento sociales efectos de la pandemia mundial que se vive, lo cual ha permitido una especie de estabilidad social, endeble sí pero ha fungido como un sostén. A pesar también de las resistencias o existencia de algunos sectores sociales que no tienen acceso a medios virtuales o deciden no utilizarlo. Sin embargo, en la mayoría se ha sostenido emocional, física, profesional, económica en gran medida por la utilización de una red Ahora bien, en este marco de acontecimientos habría que pensar y/ plantear algunos ejes de reflexión. 1) ¿El modelo económico y social vigente está por terminar? 2) ¿Estamos viendo en esta crisis actual emerger nuevas formas de organización social, política y económica? 3) ¿La sociedad está modificando prácticas sociales cotidianas que pueden quedarse durante décadas o quizá centenares?, 4) ¿En qué tipo de sociedad nos estamos transformando? 5) ¿qué función tiene la voluntad del sujeto versus ciudadano en los cambios actuales que se están dando?

Quizá estos tiempos nos muestran la movilización de una nueva fase mundial, la cual está dándose en lo contingente de diversas fuerzas existentes, y que en su devenir lo vamos dilucidando y destejiendo cual artesanos de la realidad social. Vislumbrando como lo biológico se transforma en políticoeconómico o viceversa. Quizá el virus virtual o físico llegó para quedarse. Y por ello, algunos aprendemos, mientras tanto, practicas sustentables con miras a una visión de permanencia y extinción de mercados mundiales. 